\title{
China's “One Belt, One Road” Initiative: Context, Focus, Institutions, and Implications
}

\author{
Michael M. Du \\ School of Law, University of Surrey, UK \\ m.du@surrey.ac.uk
}

\begin{abstract}
With the launch of "One Belt, One Road" Initiative, China is injecting vitality into the ancient Silk Road. While China is seen to embrace it as the centrepiece of its economic strategy, the new Silk Road Initiative, if well implemented, is expected to bring forth the opportunity of economic prosperity for both China and the countries in the region. Against the backdrop of the complicated and volatile geopolitics in the mega-regions and the voracious needs for gigantic inputs of resources, etc., however, the operationality of the Initiative is in contrast with the grandiose discourse by the Chinese authorities. In particular, where China's ultimate target is set to shape a new structure for global economic governance, its ability to lead vis-à-vis its targeted partners' readiness to cooperate, among others, remain to be tested.
\end{abstract}

\section{Keywords}

Silk Road Economic Belt - Maritime Silk Road of the 21st Century - Global governance Infrastructure connectivity - Asia Infrastructure Investment Bank

The "Silk Road Economic Belt" and "Maritime Silk Road of the 21st Century" are initiatives first introduced by Chinese President Xi Jinping in the fall of 2013 during visits to Kazakhstan and Indonesia, respectively.

The initiative consists of two main components, the land-based "Silk Road Economic Belt" (SREB) and oceangoing "Maritime Silk Road" (MSR). This modern-day Silk Road will bind together 65 countries and 4.4 billion people

(C) DU, 2016 | DOI 10.1163/23525207-12340014

This is an open access article distributed under the terms of the Creative Commons Attribution- 
from Xi'an in western China (the old imperial capital and the start of the original Silk Road), across Central Asia to the Middle East, Russia and Europe. The maritime road is designed to link the South China Sea to the Indian Ocean, east Africa, the Red Sea and the Mediterranean.

To the surprise of many observers, the Chinese president's initiative was, to his Kazakhstani host, possibly a reminder only of their shared commercial ties along the Silk Road, stretching back millennia. During a September 2013 visit to Kazakhstan, which is later regarded as the place where this initiative sprouted, Xi Jinping spoke of the Silk Road, suggesting the long-time commercial links between China and its neighbor. Xi went on to propose the establishment of a Silk Road Economic Belt to bring new prosperity to Asia. The speech sounds a typical one on a diplomatic occasion and thus barely registered in the international media. It had even failed to attract adequate attention of the Chinese media, before Xi made a further reference of the Maritime Silk Road of the 21st Century in his Indonesia visit in October 2013. But less than two years later, when the National Development and Reform Commission, the Ministry of Foreign Affairs and the Ministry of Commerce jointly promulgated the Action Plan for the so-called One Belt One Road Initiative on 28 March 2015 , the SREB/MSR strategy became a buzz word, and was formally made the centrepiece of China's foreign policy and international economic strategy. ${ }^{2}$

The sprout of the SREB/MSR strategy had its domestic economic background. China is in need of a new strategy to spur its sluggish economy. China had practiced, in the past three decades, the opening-up strategy which focused on manufacturing and exporting cheap goods. With the rise of labor costs, laborintensive goods are no longer competitive and labor-intensive industries move gradually to and aggregate in the neighboring countries. The old-fashioned opening-up strategy faces huge challenges. China is struggling to manage a difficult transition to a "new normal" of slower and more sustainable economic

1 National Development and Reform Commission, Ministry of Foreign Affairs and Ministry of Commerce, Vision and proposed actions outlined on jointly building Silk Road Economic Belt and 21st-Century Maritime Silk Road, 28 March 2015.

2 George Magnus, China's great economic journey takes it on to a new Silk Road, The Times, 20 September 2015 . 
growth. ${ }^{3}$ On the other hand, the overseas direct investment surged in the past decade, making China the third largest source of overseas direct investment (ODI) in the world in 2012, ${ }^{4}$ and a net exporter of capital in 2013. ${ }^{5}$ According to the Mistry of Commerce, China's ODI, which involved 155 destination countries, reached us $\$ 118$ billion in 2015 alone, marking an increase of $14.7 \%$ against the previous year. ${ }^{6}$ As China's ODI stock reached a peak of more than us $\$ 1$ trillion, ${ }^{7}$ China needs a new, safe, balanced and efficient opening-up strategy to boost its economy, and particularly to nurture a new round of economic development.

The strategy needs to be understood against the background of the current world economy. In face of the weak recovery of the global economy in the post-crisis era, the developed economies are still in the process of revival and adjustment. With the weak market demands and rising protectionism, they are not in a position to continue importing goods from emerging economies in large scale, and unwilling to tolerate large trade deficits from the emerging economies. In the meantime, the developed economies and emerging economies vowed to work together to upgrade the current trading system, which is expected to serve as catalyst for the world economic development; only to find that each side blamed the reluctance of the other side for failing to cooperate. ${ }^{8}$ Against this backdrop, the developed countries undertook, by their own,

3 'New normal', which is a popular term coined by President Xi during his May 2014 visit to Henan, a hinterland province, is referring to the current economic situation. According to $\mathrm{Xi}$, the economy now features more sustainable, mid-to-high-speed growth with higher efficiency and lower cost, suggesting that the Chinese economy has entered a new phase that is different from the high-speed growth pattern exhibited in the past three decades.

4 See Ministry of Commerce, State Administration of Statistics, and State Administration of Foreign Exchanges, 2012 Statistical Bulletin of China's Outward Foreign Direct Investment, available at http://images.mofcom.gov.cn/fec/201512/20151204085256581.pdf (last visited on 30 April 2016).

5 See Ministry of Commerce, State Administration of Statistics, and State Administration of Foreign Exchanges, 2013 Statistical Bulletin of China's Outward Foreign Direct Investment. An overview is available at http://fec.mofcom.gov.cn/article/tjsj/tjgb/201511/20151101190468 .shtml (last visted on 30 April 2016).

6 http://fec.mofcom.gov.cn/article/tjsj/ydjm/jwtz/201601/20160101239832.shtml (last visited on 30 April 2016).

7 http://fec.mofcom.gov.cn/article/ywzn/xgzx/guonei/201601/20160101237307.shtml (last visited on 30 April 2016).

8 After the failure of the negotiations under the wто's Doha Development Agenda in July 2008, several countries blamed each other for the breakdown. The United States and some European Union members blamed India for the failure of the talks. India claimed that its position was supported by over 100 countries. 
to shape high standard, exclusive rules for global trade and investment. As a result, the free and open global trading system is at the risk of disintegration and thus undermining the competitive advantages that the emerging countries and other developing countries have enjoyed under the existing global trading system and reducing the global market and the sources of investment influx.

Up to 2013, fundamental changes have taken place with respect to the relationship between China and the rest of the world: China has risen to be the second largest economy in the world, ${ }^{9}$ the largest exporter and the second largest importer in goods, ${ }^{10}$ the third largest source of outbound foreign direct investment, and the owner of the largest foreign exchange reserve. The economic power, its huge market potential, and its gigantic financial capacity lend China support in its economic relationship with the emerging economies: it can absorb the goods from the emerging economies in large scale, and provide needed capital to them, making it an irreplaceable market for their goods and an important source for the influx of capital in these countries. As one of the engine of the global economy, China has contributed substantially to the recovery of the world economy. According to the IMF, China contributed $27.8 \%$ to the world economic growth in 2014, topping the world in contribution to the global economic growth. ${ }^{11}$ Some Chinese experts believe that China may raise "China Proposal" or "China Solution", making it part of the "global solution". ${ }^{2}$

Nowadays, the emerging countries are collectively a rising force in the global arena. In terms of the total economic output, they are comparable to the established powers, and the multi-polarization of the world economic pattern becomes evident. Yet, the voice of the emerging economies is rarely heard in the discourse on global economic governance. The existing world economic structure and governance system were established under the Us leadership, and thus dominated by the US and European economies. The IM F committed to undertake reform so as to divert some voting rights to the emerging economies. Due to the us reluctance, no accomplishment has been achieved as planned.

9 Since 2010, China has been the second largest economy after the United States.

10 See wтo Trade Database, available at http://stat.wto.org/CountryProfile/WSDBCountry PFView.aspx? Language $=\mathrm{E} \&$ Country $=\mathrm{CN}$.

11 IMF, World Economic Outlook 2014.

12 For example, see Gao Hucheng (Minister of Commerce), A Chinese Solution to the Promotion of Global Cooperation on Development, People's Daily, 18 September 2015, p. 7 . 
It is not difficult to see that in the past decade, the World Trade Organization (WTO) fades in the new discourse of free trade, while the bilateral or multilateral negotiation on free trade agreements (FTA) flourishes. ${ }^{13}$ Apparently, the accomplishment of freer trade calls for new platform and system.

As a matter of fact, within the existing system, emerging economies have difficulty expressing their wishes, and their role as a whole in global governance is disproportionate to their powers. Now that there is no room for fundamental reform, one may naturally turn to incremental reform. The New Development Bank, which comprises Brazil, Russia, India, China and South Africa, ${ }^{14}$ is a result of such an endeavor. Unfortunately, the NDB fails to have the geo-economical support.

The SREB/MSR strategy is not intended to make a fresh start, but to integrate the existing multilateral and bilateral mechanisms into a broader framework.

3

Focus

One needs to turn to the Action Plan for a good understanding of the focus of the SREB/MSR. The Action Plan outlines five tasks to be accomplished: (1) Policy Coordination (2) Facility Connectivity (3) Unimpeded Trade (4) Financial Integration (5) People-to-People Bond. Needless to say, none of these tasks is easy to be completed. Policy coordination calls for frequent

13 The United States, Australia, Brunei Darussalam, Canada, Chile, Japan, Malaysia, Mexico, New Zealand, Peru, Singapore and Vietnam have just concluded the negotiation of the Trans-Pacific Partnership (ТРP), which sets forth high standard trade and investment rules for the Asia-Pacific region, and is supposed to deepen economic ties between these nations. For the text of the TPP, see https://ustr.gov/tpp/\#text (last visited on 30 April 2016). In the meantime, it is also negotiating with European Union the Transatlantic Trade and Investment Partnership (TTIP), which is aimed at setting forth high standard trade and investment rules for the cross-Atlantic region. It is anticipated that given the importance of the two pacts' member economies in the world, when both the TPP and TTIP are completed, the us-led trading and investment rules will become really global rules. Some analysts have even suggested that the us may be trying to use the TPP as a means to undermine China's growing economic might in the region, and isolate China with the new global rules.

14 On 14 July 2014, leaders of Brazil, China, India, Russia and India sealed on a deal in Fortaleza, Brazil for the founding of the New Development Bank. With each of the five signatories contributing \$1o billion as its initial capital, the bank works on an equal-share voting basis. The NDB will have a president (an Indian for the first six years), a Board of Governors Chair (a Russian), a Board of Directors Chair (a Brazilian), and a headquarters (in Shanghai). 
diplomatic communications among the countries along the Silk Road with a view to promoting the mind meeting of the governments of these countries, Facility connectivity requires, among others, prioritizing the key projects along the Silk Road and first of all, gigantic inputs of resources by China, Asia Infrastructure Investment Bank (ASIIB) and other countries, as well as private investors. Unimpeded trade and financial integration engender formidable work of institution-building among all the countries along the Silk Road, in the form of, for example, free trade agreement or international financial infrastructure. People-to-people bond requires intercourse and interaction between the peoples of all the countries along the Silk Road despite the cultural disparity among them.

A close look at the Action Plan, however, will find that the roadmap is notable for its mixing of traditional Chinese diplomatic language (e.g., emphasizing sovereignty and non-intervention) alongside a newer rhetorical focus on adherence to high standards and international norms. Full of Chinese style language and rhetoric, the text of the Action Plan is not always comprehensible to outsiders. While using the poetic language to describe the Silk Road and calling for the revival and carrying-on of the spirit of the ancient trade routes, it fails to appease the worrisome link between the traditional tributary system and the modern-day Silk Road. As the Action Plan is not a representation of China's unilateral commitments, nothing therein can be suggested as joint commitments of the participating partners. Unfortunately, the Action Plan is full of such expressions as "we shall' and "we should", from the reiterated governing principles to suggested actions. Moreover, vague Chinese expressions and parallel constructions can be found, which adds difficulty to the interpretation of the Action Plan.

Despite the difficulty that all this leave for the interpretation of the Action Plan, it is clear that the SREB/MSR strategy is a development strategy and framework which focuses on connectivity and cooperation among countries primarily in Eurasia. 'Connectivity' and 'Cooperation' are the key words of the SREB/MSR strategy, thus bringing forth the economic development of the Eurasia economies.

Initially billed as a network of regional infrastructure projects, the latest release of the Action Plan indicates that the scope of the SREB/MSR strategy has expanded to establish a free trade network, to promote free flow of capital, technology, personnel as well as goods, to promote the effective interaction between the East Asia economic circle and the European economic circle, and now to include promotion of enhanced policy coordination across the Asian continent, financial integration, trade liberalization, and people-to-people connectivity. 
Regarding connectivity, the SREB will on land, focus on jointly building a new Eurasian Land Bridge and developing China-Mongolia-Russia, ChinaCentral Asia-West Asia and China-Indochina Peninsula economic corridors by taking advantage of international transport routes, relying on core cities along the Belt and Road and using key economic industrial parks as cooperation platforms. At sea, the Initiative will focus on jointly building smooth, secure and efficient transport routes connecting major seaports along the Belt and Road. ${ }^{15}$

With respect to cooperation which is a guarantee to the smooth unfolding and proper implementation of the SREB/MSR strategy, the Action Plan focuses on concerted work and move toward the objectives of mutual benefit and common security. To be specific, they need to improve the region's infrastructure, and put in place a secure and efficient network of land, sea and air passages, lifting their connectivity to a higher level; to further enhance trade and investment facilitation, establish a network of free trade areas that meet high standards, maintain closer economic ties, and deepen political trust; to enhance cultural exchanges; to encourage different civilizations to learn from each other and flourish together; and to promote mutual understanding, peace and friendship among people of all countries.

4

\section{Institutions}

Empirically, it is almost certain that without facilitating institutions, there would not be smooth integration among various countries with different economic development levels, political structures and cultures; no ambitious plan like the SREB/M SR strategy can be properly implemented as planned. In light of the ambitious goal of the SREB/MSR strategy, a high standard FTA and an efficient dispute settlement mechanism, among others, are needed. Unfortunately, the existing institutions across the Asian continent are fragmented. There are already such institutions as Shanghai Cooperation Organization (SCO), ASEAN Plus China (10+1), etc. ${ }^{16}$ But none of these multilateral mechanisms is in a position to serve the SREB/MSR strategy well. Take as example the Shanghai

\footnotetext{
15 Interestingly, given its close ties with neighboring countries in South Asia, the ongoing China-Pakistan Economic Corridor and the Bangladesh-China-India-Myanmar Economic Corridor are pronounced to be closely related to the Belt and Road Initiative.

16 Other institutions include Asia-Pacific Economic Cooperation (APEC), Asia-Europe Meeting (ASEM), Asia Cooperation Dialogue (ACD), Conference on Interaction and Confidence-Building Measures in Asia (CICA), China-Arab States Cooperation Forum (CASCF), China-Gulf Cooperation Council Strategic Dialogue, Greater Mekong Subregion
} 
Cooperation Organization $(\mathrm{SCO})^{17}$ along the SREC and a free trade agreement between China and the ASEAN ${ }^{18}$ (CAFTA $)^{19}$ along the GMS. SCO was designed to be an organization facilitating cooperation among its members regarding primarily security issues. The economic integration among the sco member countries is slow and has borne no meaningful fruits, ${ }^{20}$ due to the fact that the members lack the incentive to promote an FTA among themselves. Russia, an important member of sco, has its own competing scheme. It has formulated a Eurasia Economic Union (EEU) with Kazakhstan and Belarus. ${ }^{21}$ Needless to say, Russia has no capacity and leadership if it has the intention to expand and transform the EEU into a FTA for the countries across the Eurasia. Moreover, there is no point expanding the sco to the rest of countries along the SREB; neither is there possibility of transforming the SCO into an FTA for the countries along the SREC.

So is the case with the CAFTA. It is a low standard FTA which has been far away from the forefront of FTAS. While the CAFTA used to be a focus for its "Early Harvest Package" that China offered to the ASEAN members, it lacks visibility in the arena of FTAS—-despite that both China and ASEAN are negotiating

(GMS) Economic Cooperation, and Central Asia Regional Economic Cooperation (CAREC).

17 SCO is a Eurasian political, economic and military organization which was founded in 2001 in Shanghai by the leaders of China, Kazakhstan, Kyrgyzstan, Russia, Tajikistan, and Uzbekistan. On July 10 2015, the sco decided to admit India and Pakistan as full members, and they are expected to join by 2016.

18 ASEAN stands for the Association of Southeast Asian Nations, comprising Brunei, Cambodia, Indonesia, Laos, Malaysia, Myanmar, Philippines, Singapore, Thailand, Vietnam.

19 The framework agreement was signed on 4 November 2002 in Phnom Penh, Cambodia, with the intention to establish a free trade area among the eleven nations by 2010 . The free trade area came into effect on 1 January 2010. The ASEAN-China Free Trade Area is the largest free trade area in terms of population and third largest in terms of nominal GDP.

20 Trade volume between China and other sco member states jumped from Us $\$ 12.1$ billion in 2001 to US $\$ 130$ billion in 2013. Their economic output totaled 14.9 percent of the world economy, compared with just 4.8 percent in 2001. However, sCO mechanisms for economic integration have so far ended up in such ones as the sco Business Council and sco Interbank Consortium.

21 EEU is an economic union of states located primarily in northern Eurasia. A treaty aiming for the establishment of the EEU was signed on 29 May 2014 by the leaders of Belarus, Kazakhstan and Russia, and came into force on 1 January 2015. Treaties aiming for Armenia's and Kyrgyzstan's accession to the Eurasian Economic Union were signed on 9 October 2014 and 23 December, respectively. 
an upgraded version. ${ }^{22}$ There is also no point expanding the CAFTA to the rest of the countries along the MSR.

In addition to the existing multilateral mechanisms, there are also established international forums and exhibitions at regional and subregional levels hosted by countries along the Belt and Road, as well as a few platforms such as Bo'ao Forum for Asia. ${ }^{23}$ These forums are conducive to the visibility of the SREB/MSR strategy, but it is difficult for them to carry on the strategy.

So is the case with various bilateral trade and investment agreements between the countries. China, for example, concluded trade and/or investment agreement with each country along the SREB/MSR. There is a network of such bilateral agreements of various natures, with various focuses and various degree of openness.

Should one existing agreement be selected and expanded into the framework agreement for all the countries along the SREB/MSR, or should a regional FTA be contemplated, strong leadership would be needed. No other country than China has such leadership.

The core of the SREB/MSR strategy lies in the connectivity, of infrastructures in particular. The developing countries on the Eurasia lack in capital and technology. To meet the demands, the Asia Infrastructure Investment Bank (AIIB) was founded. Up to 57 countries have committed to join the AIIB, making it a real international development bank, serving the economic development of Asia. It is anticipated that the AIIB will bring together the Chinese money, European expertise and the demands of the Asia's developing economies, and lay down the financial foundation for the implementation of the SREB/MSR strategy.

In this regard, no one can afford ignoring the role of a working dispute settlement mechanism in the implementation of the SREB/MSR strategy. Varied

22 China and the ASEAN members have set a goal to conclude the negotiations on upgrading the China-ASEAN Free Trade Agreement by the end of 2015 .

23 Bo'ao Forum for Asia is a non-profit organisation that was initiated and supported by the Chinese government. It hosts high-level forums for leaders from government, business and academia in Asia and other continents to share their vision on the most pressing issues in this dynamic region and the world at large. BFA is modeled after the World Economic Forum held annually in Davos, Switzerland. Other platforms include ChinaASEAn Expo, China-Eurasia Expo, Euro-Asia Economic Forum, China International Fair for Investment and Trade, China-South Asia Expo, China-Arab States Expo, Western China International Fair, China-Russia Expo, Qianhai Cooperation Forum, Silk Road (Dunhuang) International Culture Expo, Silk Road International Film Festival and Silk Road International Book Fair. 
interests or varied perceived interests, varied legal systems, varied cultures among the countries are likely to give rise to disputes, which in turn hamper the smooth implementation of the strategy. Designing and having in place a dispute settlement mechanism shall be given priority in all the agenda concerning the SREB/MSR strategy.

\section{$5 \quad$ Implications}

Like the conclusion of the TPP, the release of this strategy attracted the eye of the world. Observers are mostly concerned with the objectives of SREB/MSR and its influence vis-à-vis those of the TPP. While China always highlights the economic output the plan will bring out, international observers focus more on China's interests and the threats the strategy may cause rather than its economic aspects. Some outside observers downplay the strategy as another symbolism showing Beijing is trying to claim a place as Asia's dominant economic and military power. It adds the annual Asia Pacific Economic Cooperation summit as a supporting example which "is set to endorse for the first time a "blueprint on regional connectivity" over the next decade." A reference to the APEC is strongly suggesting that the SREB/MSR strategy is an unwieldy attempt and merely a declaration of grandiose goal.

\begin{tabular}{|c|c|c|}
\hline & TPP & SREB/MSR \\
\hline $\begin{array}{l}\text { Agreement or } \\
\text { initiative }\end{array}$ & $\begin{array}{l}\text { A mega-regional trade } \\
\text { agreement. }\end{array}$ & $\begin{array}{l}\text { An initiative rather } \\
\text { than an agreement, } \\
\text { involving no } \\
\text { agreement. }\end{array}$ \\
\hline $\begin{array}{l}\text { Exclusive or open to a } \\
\text { third party }\end{array}$ & $\begin{array}{l}\text { US-led. } \\
\text { High membership } \\
\text { requirements including } \\
\text { rounds of negotiation } \\
\text { special entry criteria rule } \\
\text { out China's participation } \\
\text { at present. }\end{array}$ & $\begin{array}{l}\text { Initiated by China. } \\
\text { China is seeking } \\
\text { support from countries } \\
\text { along the Silk Roads } \\
\text { open to any country } \\
\text { The Us is not involved } \\
\text { and apparently does } \\
\text { not plan to be. }\end{array}$ \\
\hline Economic links & $\begin{array}{l}\text { Should consolidate } \\
\text { economic ties, especially } \\
\text { with Japan and ASEAN } \\
\text { countries. }\end{array}$ & $\begin{array}{l}\text { Will create a network } \\
\text { of infrastructure (road, } \\
\text { rail, ports, electricity, } \\
\text { energy), trade and }\end{array}$ \\
\hline
\end{tabular}


(cont.)

\begin{tabular}{|c|c|c|}
\hline & TPP & SREB/MSR \\
\hline \multirow{8}{*}{$\begin{array}{l}\text { Economic and geopo- } \\
\text { litical influence }\end{array}$} & $\begin{array}{l}\text { For the Us, expected to } \\
\text { create job opportunities } \\
\text { and increase exports to, } \\
\text { and investment with, } \\
\text { member countries. }\end{array}$ & $\begin{array}{l}\text { finance connections } \\
\text { between China and } \\
\text { other countries. } \\
\text { For China, } \\
\text { providing an outlet } \\
\text { for production } \\
\text { overcapacity and } \\
\text { overseas investment. }\end{array}$ \\
\hline & Expected to consolidate & Aimed at making \\
\hline & $\begin{array}{l}\text { US Involving } 12 \\
\text { signatories accounting } \\
\text { for more than } 40 \text { per } \\
\text { cent of global GDP and a } \\
\text { population of nearly } 800 \\
\text { million. }\end{array}$ & $\begin{array}{l}\text { China the Involving } \\
\text { some } 65 \text { countries, } \\
\text { some } 4.4 \text { billion } \\
\text { people, or } 63 \text { percent } \\
\text { of global population } \\
\text { Economic powerhouse }\end{array}$ \\
\hline & Power and market & of the region. \\
\hline & influence in Asia & Seen as a strategy to \\
\hline & Pacific, especially Asian & lower the negative \\
\hline & countries. & impact of TPP on \\
\hline & & China. \\
\hline Rule-based or not & Rule-based & Unknown yet \\
\hline
\end{tabular}

Indeed, the SREB/MSR strategy is in contrast with the TPP. Unlike TPP, a high standard mega-regional free trade agreement, it is at its heart a pledge by China to use its economic resources and diplomatic skill to promote infrastructure investment and economic development that more closely links China to the rest of Asia and onward to Europe. In this regard, it seems to reflect China's preference to avoid if possible formal treaties with measurable compliance requirements in favor of less formal arrangements that give it flexibility and allow it to maximize its economic and political skills, as well as recognition of the difficulty of building its Belt and Road. Indeed, the establishment of the Belt and the Road will not be an easy task. A great deal of deliberation and negotiation may be necessary among the countries along the Belt and the Road for generating necessary political interest in and support for these 
mega-connectivity projects and viewing mutual benefits in them and for harmonization of customs \& financial rules and regulations, removal/lowering of tariff and non-tariff barriers, trade and investment facilitation, etc, in order that desirable economic integration may be achieved. Negotiation at the bilateral and multilateral levels has to be carefully planned and commenced on all these matters and areas.

A major issue would be building or development of appropriate infrastructural facilities in all the counties along the Belt and Road for the unfolding and smooth operation of the strategy. Many of the countries need financial and technical assistance in this regard. China might be required to provide a huge chunk of it. This will be a test of China's capacity and willingness to channel formidable resources to the regional infrastructure development. An early commencement of the functioning of the Asian Infrastructure Investment Bank will be a major step forward in this arena. Even if enough resources can be made available to the infrastructures, there are also risks. For example, many of China's past bilateral investment deals in Africa and Asia based around access to commodity resources were not commercially viable, poorly implemented and, in some cases, unpopular locally. ${ }^{24}$ Improperly implemented, the SREB/MSR strategy would well end up as little more than a series of expensive boondoggles.

Of course, it is premature to predict whether the SREB/MSR strategy is doomed to end in failure or will mark the start of a China era in global economic governance. But, it is instrumental to outline the problems and challenges facing the implementation of the strategy, and to explore the implications of the SREB/MSR strategy for China, if properly implemented, for the participating partners, and for the global governance separately.

24 China Harbor Engineering Co. Ltd., a wholly owned subsidiary of state-owned China Communications Construction Co., was contracted by the Sri Lanka government to invest Us $\$ 1.5$ billion to build Colombo Port City. It would build berths for vessels at the nearby port, hotels, shopping centers, office buildings and residential complexes, covering a total area of more than 5.3 million square meters. The deal was to give the Chinese investors 1.08 million square meters of land in the area, some of it outright and the rest on a 99-year lease. While the port project would have been the largest foreign direct investment Sri Lanka has received, the Chinese government held it dear as a pioneering project for the Maritime Silk Road strategy. However, the project spurred controversy in Sri Lanka, as some criticized it violated local laws and regulations and would damage the environment. Soon after the newly elected government came to office in March 2015, it announced its decision to hold off on the project while assessing its impact on the environment. 


\section{Implications for China}

The SREB/MSR strategy is expected to feature prominently in China's 13th FiveYear Plan, which will run from 2016 to 2020 and guide national economic and social development strategy throughout that period. Its immediate implications are as follows:

The strategy will secure the transport of oil and gas and other essential goods, and particularly access to the Central Asian energy resources needed to sustain China's economy.

The property and investment boom at home has now ended, leaving China with significant overcapacity in industry and construction, deflation and rising debt management problems. The implementation of the strategy can ease the entry of Chinese goods into regional markets, help make use of China's enormous industrial overcapacity, thus offsetting the effects of a falling investment rate and rising overcapacity at home.

China has been tired of accumulating endless volumes of us Treasury and other government bonds, and now prefers more direct investment overseas to make a better use of its more than $\$ 4$ trillion foreign exchange. Equally important, the SREB/MSR can improve internal economic integration between the country's advanced coastal and the more backward western provinces. These are the strategy's intermediary implications.

With respect to the long-term implications, by linking the economies of Central Asia with western China, China is expected to bring further development and stability to restive and relatively underdeveloped Xinjiang and Tibet regions and cuts off any potential support that Uygur dissident groups may seek from fellow Muslims in Central Asia. With the unfolding of the SREB/MSR strategy, China will be in a position to promote the global use of RMB which is likely to lead to the internationalization of Rмв.

\section{Implications for Partners}

Needless to say, the SREB/MSR strategy will have its implications for the participating countries along the Belt and Road. Properly implemented, the SREB / MSR strategy will likely have an important effect on the region's economic architecture-infrastructure development, patterns of regional trade and investment. However, this rests on their own perception of interests therein and the extent of cooperation they offered. It is not surprising if they argue SREB/MSR is too China-centric and that other participating states will reap only marginal benefits. 


\section{Implication for Global Governance}

China has long expressed opposition to the dominance of the us and the dollar in the global financial institutions, most notably the International Monetary Fund and the World Bank.

The SREB/MSR strategy is the upgraded version of China's grand strategy of opening-up, as well as China's strategy for globalization. Globalization has been so far mainly driven by the West. With the unfolding of the SREB/MSR strategy, non-Western countries are going to inject vitality. The Chinese version of globalization needs to nurture shared interests, shared system and effective dispute settlement mechanism.

Another concern is that some Western officials also fear that a flood of Chinese development money will undermine governance standards at existing lending institutions like the World Bank, especially if China channels funds to its own companies, to politically motivated projects or to environmentally damaging ones.

An even deep concern beneath, which results from the distaste for the Chinese governance structure and state-led economic structure, is whether China will extend and deepen its global footprint without fundamental changes in political and economic philosophy.

\section{$6 \quad$ Concluding Remarks}

The SREB/MSR strategy is an ambitious economic vision of the opening-up of and cooperation among the countries along the Belt and Road. It is aimed to establish a free and open market system in the heartland of Eurasia, and reshape the geo-economic order.

Inevitably, this will require China to project its growing power further. After all, this strategy would simply be a commercial but truculent riposte to America's pivot to Asia. Important commercial consequences for the region and global companies will go hand-in-hand with unpredictable geopolitical implications in parts of the world where the us - and even Japan, India and Russia-has material and competing interests. In this context the operationality of the strategy is in contrast with the grandiose discourse by the Chinese authorities. 